\title{
INTERNATIONAL CODE OF NOMENCLATURE FOR CULTIVATED PLANTS
}

\section{Mildred Mathias}

The need for a comprehensive set of rules to govern the naming of cultivated plants has been evident for many years. Since the initial suggestions by DeCandolle in 1862 horticulturists and botanists have been working on a code applicable to the problems of naming cultivated plants. This Code was formulated and adopted, after many years of study, by the International Botanical Congress Committee for the Nomenclature of Cutlivated Plants and the International Committee on Horticultural Nomenclature and Registration at the Thirteenth International Horticultural Congress, London, September, 1952. (Copies are available at $25 \propto$ a copy from the Secretary, American Horticultural Council, Inc., Bailey Hortorium, Cornell University, Ithaca, N. Y.)

It is important that a precise, stable and internationally accepted system of nomenclature be available and "the aim of this Code is to promote uniformity, accuracy and fixity in the use of names with the minimum disturbance of existing nomenclature." The Code should be studied in entirety either in the condensed or the full text. The following are provisions of general interest to all plantsmen:

1. The much misused term 'variety' is to be reserved for those forms of cultivated plants which are known to occur in the wild and which have names in Latin form.

2. The term 'cultivar' (abbreviated as cv.) is to be used for all those forms which have oirginated or are maintained only in cultivation.

3. From 1 January, 1954, onward no new cultivars should be named in Latin but should have a common name. 'Pygmy' not pygmaeus.

4. The cultivar-name should begin with a capital letter and be distinguished from the Latin botanical name, preferably by enclosing it in single quotation marks.

5. Latin names given to cultivars before 1 January, 1954, are not to be rejected but should be typographically distinguished from Latin names of botanical varieties.
6. The same cultivar-name should not be used twice in the same genus.

7. A name has no standing under this code unless validly published or officially registered. (Valid publication and registration are defined.)

8. A set of rules is given for the naming of hybrids.

The following are examples of correct names for cultivated plants:

Syringa vulgaris 'Mont Blanc' or Lilac 'Mont Blanc'

Thuja orientalis 'elegantissima'

Fagus sylvatica atropunicea (a botanical variety although in cultivation)

Fagus sylvatica 'riversii' (a particular clone)

Crocus sieberi 'Hubert Edelsten' and not $C$. sieberi 'Edelsten's variety.'

Rose (Hybrid Tea) 'Richmond'

Lilium x 'Shuksan' or Lilium (Bellingham Hybrids) 'Shuksan'

This Code can only achieve its aims if it is adequately supported and widely adopted. "The breeders and introducers of new plants are urged, in their own interest, to give names which are in accordance with the Code. Seedsmen and nurserymen should try to bring their catalogues into line with it. Registering authorities should refuse to register names not in accordance with the Code; no awards should be given to plants not named in accordance with the Code. Specialist societies should use it as a basis for their own codes of nomenclature. Writers on cultivated plants should endeavor to employ only names correct according to the Code; by frequently mentioning the Code as a standard of procedure they will help to make it known and appreciated." The Code can be modified and revised if genuine trial reveals the need for any changes.

In accordance with these recommendations and following the lead of other horticultural journals Lasca Leaves will in the future follow the provisions of the Code.

The dream of peace on earth is strongly rooted in the human heart, but it was not in the mind of the architect when he planned the theater of the world, nor of the director when he cast the players for their several roles. The original plan that terrestrial history shall unfold with turmoil has never suffered any significant alteration. The dead earth over which the pageant of life has streamed these many eons is dead only to the eye that does not see it as it really is. Through the ages conflict has marked the sojourn not only of plants and animals, but also the clod beneath them." 


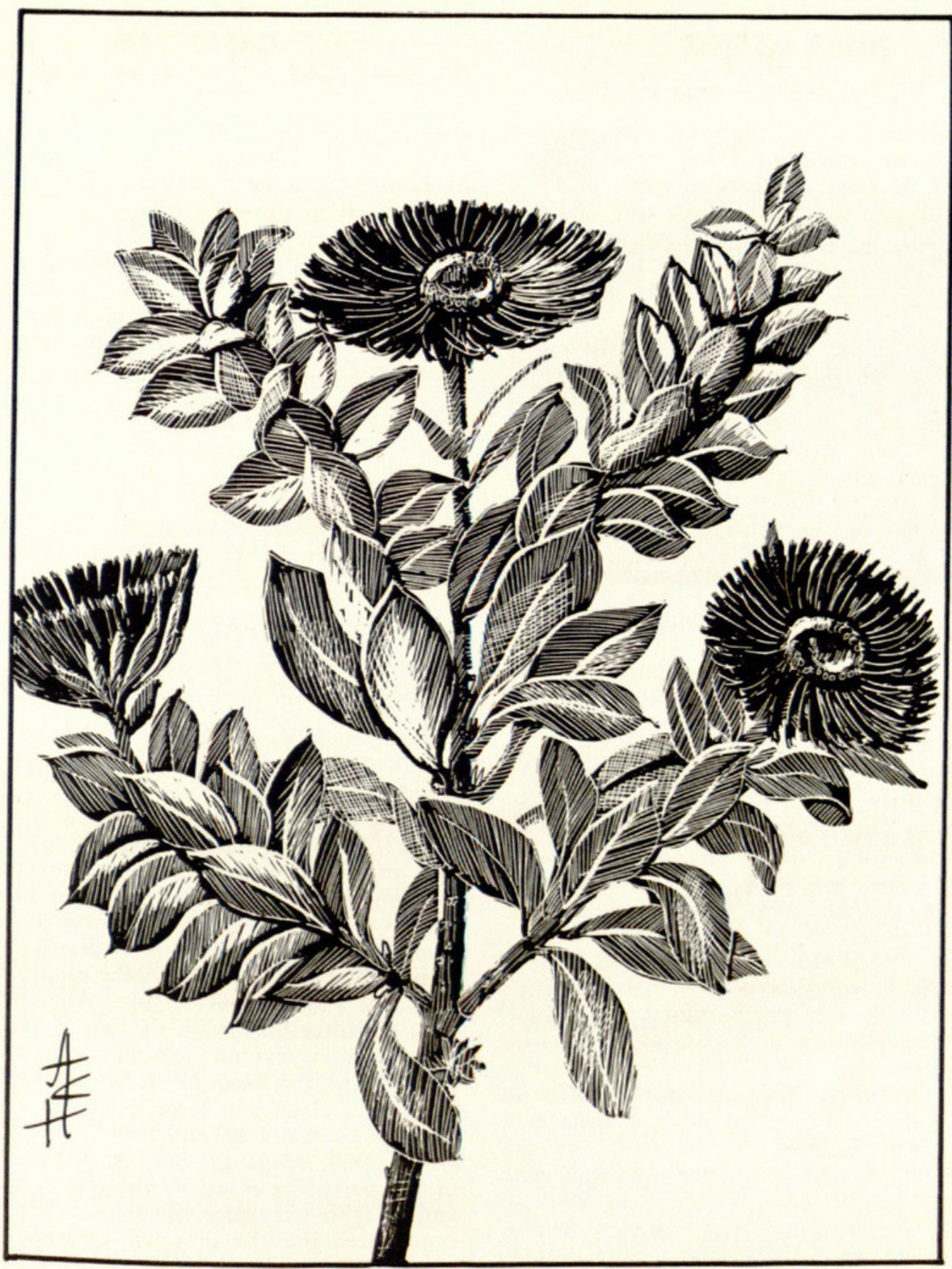

SCRATCHBOARD SKETCH BY ALFRED HOTTES

Odontospermum sericeum

O-don-to-sper'-mum, (tooth plus seed). Compositae fam. (e.g. daisy, sunflower).

The Canary Cowseye, Odontospermum sericeum, comes from the Canary Islands and was introduced to England in 1779 and to California culture by Hugh Evans. The plants grow about 2 feet tall and are very compact. The silky-hairy leaves give a whitish appearance. The leaves are opposite though they do not seem that way as they are clustered. They are oblong spatulate and apple-scented when crushed. The golden yellow daisies are solitary, 2 to 3 inches in diameter. The ray florets are 3 -toothed at the tip. The plants are always in bloom when weather permits. Uses. This is definitely a shrub for welldrained slopes and the semi-wild spot, but inasmuch as it has gray foliage it is always desirable for the gray garden.

Culture. Odontospermum does not want too much water but a warm, sunny welldrained spot. Prune back frequently to keep the plants in good form and to extend the blooming season. It tolerates a temperature of 28 degrees. 


\section{$2 \mathrm{BHL}$ Biodiversity Heritage Library}

Mathias, Mildred Esther. 1954. "International code of nomenclature for cultivated plants." Lasca leaves 4(Winter 1954), 20-21.

View This Item Online: https://www.biodiversitylibrary.org/item/129410

Permalink: https://www.biodiversitylibrary.org/partpdf/124919

\section{Holding Institution}

Missouri Botanical Garden, Peter H. Raven Library

\section{Sponsored by}

Los Angeles Arboretum

\section{Copyright \& Reuse}

Copyright Status: In copyright. Digitized with the permission of the rights holder.

Rights Holder: The Arboretum Library at the Los Angeles County Arboretum and Botanic Garden

License: http://creativecommons.org/licenses/by-nc-sa/4.0/

Rights: https://www.biodiversitylibrary.org/permissions

This document was created from content at the Biodiversity Heritage Library, the world's largest open access digital library for biodiversity literature and archives. Visit BHL at https://www.biodiversitylibrary.org. 